\section{B A Institute of \\ YK Business Administration \\ 六下 \\ Karachi \\ Leadership and Ideas for Tomorrow}

Business Review

Volume 10 Issue 2 July-December 2015

7-1-2015

\title{
Literary Note on: Donna Tartt; The Secret History: New York: Vintage, Paperback, 569PP
}

Nadya Chishty-Mujahid

Institute of Business Administration, Karachi

Follow this and additional works at: https://ir.iba.edu.pk/businessreview

Part of the English Language and Literature Commons, and the History Commons

\section{c) (7)}

This work is licensed under a Creative Commons Attribution 4.0 International License.

\section{Recommended Citation}

Chishty-Mujahid, N. (2015). Literary Note on: Donna Tartt; The Secret History: New York: Vintage, Paperback, 569PP. Business Review, 10(2), 188-189. Retrieved from https://doi.org/10.54784/ 1990-6587.1362 


\title{
LITERARY NOTE
}

\section{DONNA TARTT; THE SECRET HISTORY: NEW YORK: VINTAGE, PAPERBACK, 569PP}

\author{
Nadya Chishty-Mujahid \\ Institute of Business Administration, Karachi
}

\begin{abstract}
Donna Tartt's postmodern classic gained great fame when published in 1992, and additional, well-merited recognition when its author won the Pulitzer Prize for her more recent novel The Goldfinch in 2014. Originally from Mississippi, Tartt relocated to the East Coast during her college years and struck up friendships with notable literary figures such as Bret Easton Ellis - a move that enabled her to indulge in her passion for writing and bring her undeniable creativity to the public's attention. For sheer twisted machinations, The Secret History has few comparable rivals in postmodern literature, with the exception of great works such as Katherine Dunn's Geek Love, a modern-day Wuthering Heights.
\end{abstract}

Set at a tony and prestigious Vermont college, Hampden, the story focuses on the protagonist Richard Papen, a middle-class boy from California whose deep interest in Ancient Greek leads him to an eccentric and brilliant professor, Julian Morrow. It turns out that Julian chooses his students selectively and based on a deep elitism, but Richard's determination to hob-nob with the likes of them wins out over initial opposition to his joining the clique. His Classical Studies mates are an odd bunch - a brilliant linguist named Henry, an anachronistic, Wildean-style homosexual called Francis, a pair of twins improbably named Charles and Camilla, and the most problematic of all-Bunny Corcoran, whose inability to match up to the others intellectually and emotionally, proves fatal for him.

As the novel progresses, Richard discovers much to his horror that Henry, Francis and the twins have engaged in an alcohol-driven Bacchanal frenzy that has resulted in them inadvertently killing a simple, Vermont farmer. Matters get complicated when the group realizes that the self-absorbed and slightly stupid Bunny cannot keep his mouth shut about the matter. To protect themselves they simply push him off a cliff, but the act results in further problems for them, leading them down horrific psychological avenues of depression, guilt, alcoholism and violence. The fact that they are intense and cerebral is more of a curse than a blessing, as Tartt relentlessly emphasizes that the increasing divide between their moral and mental selves can lead only to madness. Henry's arrogance, Francis' repressed sexuality, the twins' ridiculously incestuous relationship, and Richard's societal complexes make for intriguing reading, but the writing occasionally suffers from a long-winded wordiness that could easily have been amended by more vigilant editorship on the part of its talented author. The most gripping portions of the book revolve around the elitist, but dangerously impoverished, Bunny's ability to milk his 'friends' financially for all they are worth-a fine example of the mental torture that blackmailers invariably inflict on their victims. Richard is the nicest of the group, but the tragedy of the novel is that nothing nice can ultimately thrive in the twisted environment of Julian Morrow's ivory tower.

Novels that situate themselves in relation to deep realms of erudition, such as the study of ancient classical languages automatically earn the label of 'pretentious,' but Tartt was originally herself a down-to-earth girl from the Deep South with a sound grasp of the universalevils of human nature, the ugly and overt display of which cannot be laid at the door of any particular culture or creed. In some ways the pretentiousness of Morrow's students is little more than a necessary façade created by the novelist; beneath that carefully cultivated exterior they are all susceptible to the deep anxieties and frustrations that plague young college students. In a strangely Shakespearean manner reminiscent of the way in which the 
classically-named characters of A Midsummer Night's Dream suffer from the domino effects of misplaced sentiment, Francis falls in love with Charles, who in turn falls in love with his own sister, who gets infatuated by Henry, who ultimately is most infatuated by his books. The bumbling Bunny and wretched Richard are the only ones who (like Heathcliff's longsuffering Nelly Dean) remain on the periphery of not just the disastrous Bacchanal referred to above, but also the convoluted relationship dynamics that detrimentally affect their four other friends. Tartt's prose is often elegant and generally engaging, so the novel proceeds at a fairly rapid pace in spite of a rather simple set of plot machinations. Nevertheless, one wishes more attention had been paid to developing the character of Julian, a Renaissance figure similar to the greatPomponio Leto who enticed such devoted followers to his mysterious quattrocentoRoman Academy.

Classical Greek and Latin are known for being notoriously difficult to master, but the lure of the Greco-Roman myths affects a much wider audience than a primarily scholarly one. Anglophone speakers of a few decades ago could read children's versions of the myths by Roger Lancelyn Green and then progress to reading Robert Graves, the Romantic poets, and great Augustan translations of the Homeric and Virgilian epics. Even today, Percy Jackson (a New York based son of Poseidon) holds sway over the lives of thousands of teenagers. But that the ancient pagans were capable of enormous cruelty and violence comes as no secret to anyone who has heard of Orestes, Oedipus or Troy. The chilling beauty of Tartt's ethos can be encapsulated in the famous Latin saying: 'Those whom the gods wish to destroy, they first drive mad.' In spite of all the reassurances of the great present-day religions, as far as Tartt's world is concerned the saying still holds true. 送送

I'm content to have people think I live in a cave and wear horns. Eleanor McClatchy

David Olive \& Gita Piramal, The Quotable Tycoon: A treasury of business quotations, Page 133 